\title{
Growth and Early Laying Performance of Pullet Chickens Fed Sorghum Based Diets Supplemented with Enzymes
}

Onimisi, P. A., Agunbiade, O. M. and Omage, J. J.

Department of Animal Science,

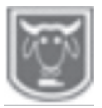

Abstract

Ahmadu Bello University, Zaria Nigeria.

Corresponding author: onimisiphil@gmail.com

GSM: +234 8057228486

A study was carried out to evaluate the effect of replacing maize with sorghum and supplementation with enzymes, on the growth and laying performance of laying chickens. Four hundred and fifty 12-weeks old Lohmann Brown pullets were distributed randomly into six dietary treatments with three replicates per treatment, each replicate had 25 birds with uniform group weights at the initial stage of the study. The treatments included maize without enzymes (T1) and sorghum without enzymes (T2) as two controls respectively, while T3, T4, $T 5$, and T6 contained sorghum based diets with phytase, protease, roxazyme G2G, and a combination of protease and roxazyme G2G respectively. The experiment lasted from 12 to 32 weeks of age of birds during which data were collected on growth and early egg laying performance of birds. Data obtained were subjected to analysis of variance, using the completely randomized design (CRD). Significant differences among treatment means were compared using the Tukey test. Significant $(p<0.05)$ differences were noted in final weight $(\mathrm{g} / \mathrm{bird})$, weight gain $(\mathrm{g} / \mathrm{bird})$, daily weight gain $(\mathrm{g} / \mathrm{bird})$, total feed intake $(\mathrm{g} / \mathrm{bird})$, daily feed intake (g/bird/day), and feed to gain ratio. Final weight and weight gain were significantly $(p<0.05)$ better for birds in T4 (sorghum + protease) compared to the other treatments, but was similar to T1 (control). At the early laying stage, no definite trend was observed among the egg production traits. However, dietary treatment supplemented with phytase (T3) had the highest numerical values for; weight of first egg (54.28g), number of eggs at peak lay (24.00), hen house egg production $78.84 \%$, and hen day egg production, $81.09 \%$. It was concluded therefore, that sorghum with phytase and protease supplementations can be used in layers' diets for optimum egg production. It is recommended that phytase supplementation at $0.02 \%$ with sorghum can be incorporated into the diets of egg type chickens for optimum performance.

Keywords: Sorghum, Pullets, Enzymes, Growth Characteristics, Egg Laying Performance

\section{Introduction}

Maize has remained the main energy source in compounded diets and constitutes about $50 \%$ of poultry ration (Ajaja et al., 2002). According to Etuk (2008), these trends require serious diversification of energy feedstuff for poultry. The fact that feed alone accounts for $70-80 \%$ of the production inputs in intensive monogastric animal production, makes the utilization of cheaper and alternative feed ingredients expedient. The main aim of using nonconventional feed ingredients is to reduce the cost of production thus making it possible for an average Nigerian to be able to afford animal protein in their meals (Olabanji et al., 2009).

Sorghum bicolor (L) Moench is widely grown in the semi-arid and arid savannah regions of Nigeria. Maunder (2002) reported that, sorghum is a traditional crop in much of Africa and Asia, and an introduced and hybridized crop in the western hemisphere. In terms of the nutritive value, cost and availability, sorghum grain is the next alternative to 


\section{Sorghum based diets supplemented with enzymes}

maize in poultry feed (Subramanian and Metta, 2000). Several varieties of sorghum have been developed and introduced in Nigeria such as PRADHAN, MLSH 296 Gold, MLSH 151, SAMSORG-3, S A M S OR G - 5, S A M S O R G - 6, SAMSORG-16, SAM SOR G-17, SAMSORG-40, SAMSORG 42, SAMSORG 43, SAMSORG 44 (IAR, 1999). Field observations in Nigeria revealed the inclusion of sorghum in poultry and rabbit diets (Abubakar et al., 2006; Etuk and Ukaejiofo, 2007). Sorghum however, contains some anti-nutritional factors which inhibit the use of important nutrients like protein, energy and minerals in diets. These anti-nutritional factors include trypsin inhibitors (protease inhibitor), saponins, oxalates, tannins haemagglutinins (lectins), phytic acid/phytate, and indigestible carbohydrates such as oligosaccharides and non-starch polysaccharides (Marsman et al., 1997; Graham et al., 2002).

Feed enzymes have the potential to reduce effects of anti-nutritional factors, render nutrients more available for digestion and absorption, increase energy value of feed ingredients and allow for greater flexibility in feed formulation, thus reducing formulation costs and modulating or stabilising gut microflora. Some of the enzymes that have been used over the past several years and have potential for use in the feed industry include cellulase $(\beta$ glucanases), xylanases and associated enzymes, phytases, proteases, lipases, and galactosidases. Supplementing poultry diets with these exogenous enzymes can improve digestion of nutrients from feedstuffs, thereby decreasing feed costs and improving bird performance (Silversides and Hruby, 2009; Khusheeba and Sajid, 2013). The aim of this study was to determine the effect of enzymes supplementation on performance of egg type chickens fed sorghum based diets. The specific objective was to evaluate the growth and early laying performance of pullets fed sorghum based diets supplemented with phytase, protease, and roxazyme $\mathrm{G} 2 \mathrm{G}$.

\section{Materials and methods \\ Location of the Study}

The study was conducted at the Animal Science Teaching and Research Farm, Ahmadu Bello University, Zaria, Nigeria. Zaria is located within the Northern Guinea Savannah zone of Nigeria, latitude, $11^{0} 14^{\prime}$ $44^{\prime} \mathrm{N}$ and longitude $7^{\circ} 38^{\prime} 65^{\prime} \mathrm{E}$, at an altitude of $610 \mathrm{~m}$ above sea level. The climate is relatively dry, with a mean annual rainfall of $700-1400 \mathrm{~mm}$, occurring between the months of April and September (Ovimaps, 2015).

\section{Experimental birds and other materials used}

The Lohmann Brown pullet growers were used. Sorghum (Kaura variety) was purchased from the open market in Samaru, Zaria. The other ingredients for the experiment were purchased from Musphaza Agro Allied Investment Company Limited, Kaduna.

\section{Experimental design}

Four hundred and fifty 12-weeks old Lohmann Brown pullets were distributed randomly into six treatments with 3 replicates per treatment, each replicate had 25 birds with all the replicates having uniform group weights, and Completely Randomized Design (CRD) was used. The experiment lasted up to 32 weeks of age of the birds, i.e 20 weeks period.

\section{Experimental diets}

The experimental diets were formulated as follows; $\mathrm{T} 1$ = maize based diet without enzyme served as the control; $\mathrm{T} 2=$ sorghum based diet without enzyme as a second 
control, $\mathrm{T} 3=$ sorghum based diet with phytase, $\mathrm{T} 4=$ sorghum based diet with protease, $\mathrm{T} 5=$ sorghum based diet with roxazyme $\mathrm{G} 2 \mathrm{G}, \mathrm{T} 6$ = sorghum based diet with Protease and roxazyme G2G.

However, layer's diet was introduced when the birds reached 21 weeks of age. The composition of the diets and calculated analysis are as shown in Table 1.

\section{Data collection}

Growth parameters measured included, final weight, weight gain, feed intake, feed conversion ratio. The early egg laying performance parameters measured included weight of birds at first egg, weight of first egg, age at first egg, age at 10\% lay, age at $50 \%$ lay, and age at peak lay. Other parameters included; number of eggs at peak lay, percentage en day egg production
(HDP), percentage hen housed production (HHP) at peak lay, egg number per hen, and egg mass.

The HDP and HHP were calculated using the following formulae;

HDP \%...

$$
\mathrm{HDP}=\frac{\text { Total number of eggs produced }}{\text { Number of Hen days }} \times 100
$$

Where "Hen days" = Number of hens x Number of days in lay

HHP $=\frac{\text { Total number of eggs laid }}{\text { Total number of hens housed at the beginning of laying Period }} \times 100$

\section{Data analysis}

Data generated on growth and early laying performance were subjected to analysis of variance using General Linear Model procedure for statistical analysis, while Tukey Test was used to separate significant differences between means (SAS, 2001).

Table 1: Composition of experimental pullet growers diet

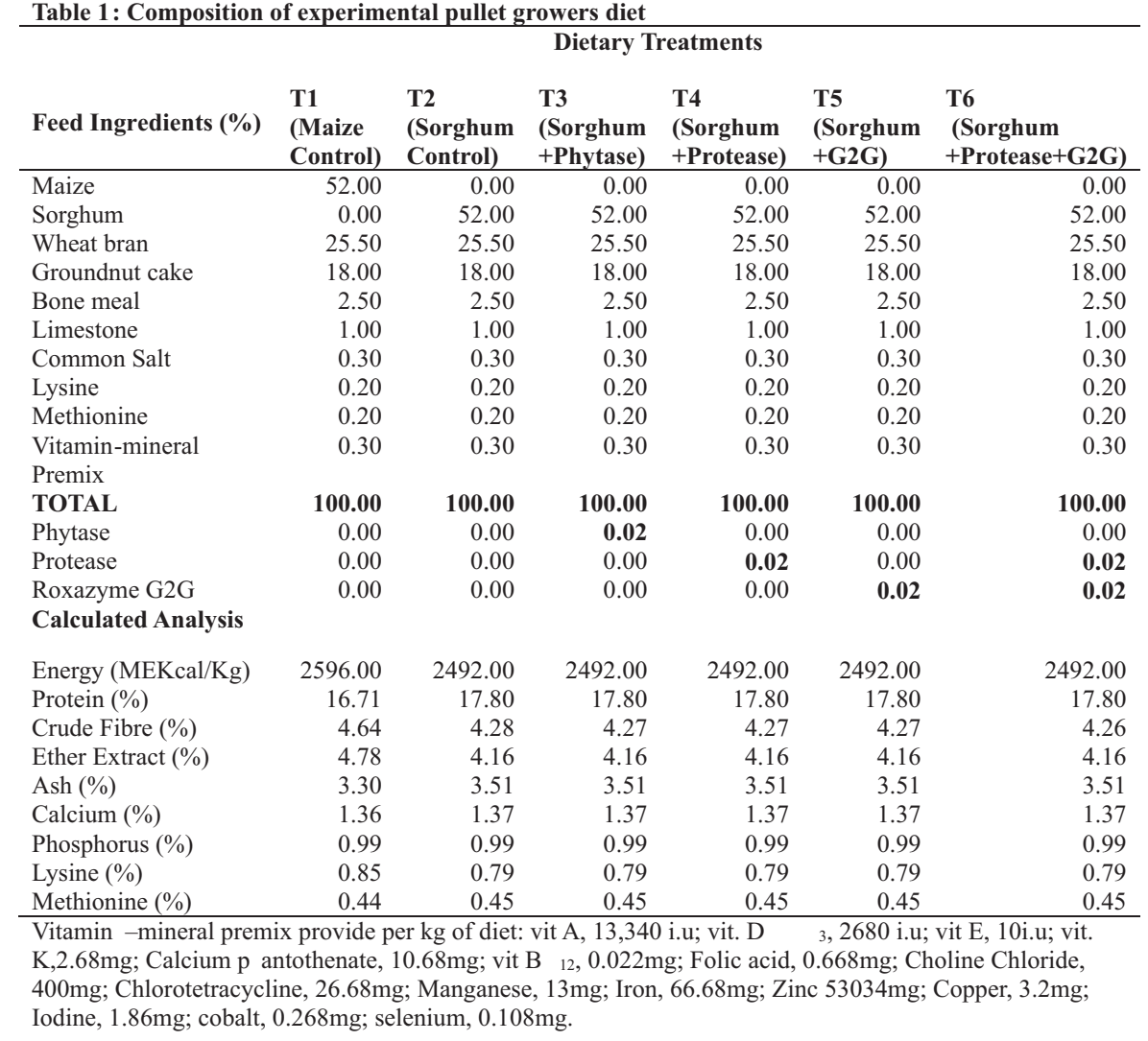




\section{Sorghum based diets supplemented with enzymes}

\section{Results and discussion}

The growth performance is represented in Table 2. There were significant $(p<0.05)$ differences among for final weight, weight gain, daily weight gain, total feed intake, daily feed intake and feed to gain ratio. However, maize control and sorghum plus protease diets were significantly $(p<0.05)$ higher compared to all other dietary treatments for only final weight, weight gain, and daily weight gain. Total feed intake and daily feed intake were similar in maize control, phytase, protease and G2G diets, which were not significantly different ( $>>0.05)$.

Significant differences were observed among the dietary treatments fed sorghum supplemented with specific enzyme additions on growth performance of layer hens at age of 12-32 weeks. Higher final weight and consequently average daily weight gain (g/day) observed in birds fed diets supplemented with protease enzyme was comparable with that of the maize based diet. This agrees with reports on the impact of exogenous enzyme supplementation on growth performance of farm animals in general. Such impact as cited was not limited to improvement of the nutritive value of feed stuffs but also reduction in the variability in nutritive value between feedstuffs and improving the accuracy of feed formulations (Pariza and Cook, 2010; Munir and Maqsood, 2013).

This improvement observed in this study may probably be due to an increase in nutrients release from sorghum by the action of the enzyme supplemented especially the protease. The results indicate that the efficiency of dietary utilization especially protein increased in chicken fed protease enzyme-supplemented-diet compared to those fed the control and other enzymes.

Variations in total feed intake among the dietary treatments may be attributed to the level of the anti-nutritional factors present in the feed, and the form of enzyme supplementation. Also, there were significant differences among all the measured parameters (weight gain, daily weight gain, total feed intake, daily feed intake and feed to gain ratio). Trend obtained from this study is in contrast with the report of Lumpkins et al. (2005) who showed no difference in daily feed intake, weight gain and total feed intake for hens fed up to 15 or $20 \%$ distillers dried grain.. The reduction in feed to gain ratio due to enzyme supplementation in this study is in agreement with earlier findings (Jackson et al., 2004 and Onu et al., 2011). These researchers reported that exogenous enzymes greatly improved the feed conversion abilities of broiler chicks and growing pullets fed enzyme supplemented diet as observed in this study.

Increase in total feed intake in this study was corroborated by the observation that birds eat more to meet their energy requirements to sustain growth and development. Pettersson and Aman (2007) tested the addition of an enzyme cocktail, to an unpelleted poultry diet containing rye and wheat, and reported a significant increase in body-weight and feed intake. Therefore, the supplementation of the animal feed with suitable enzymes to increase the efficiency of digestion can be seen as an extension of the animal's own digestion process.

The early laying performance of pullets fed sorghum based diets is shown in Table 3. Dietary treatment differed significantly $(p<0.05)$ for weight of birds at first egg, weight of first egg, age of bird at first egg, age at $10 \%$ lay, number of eggs at peak lay, $\% \mathrm{HHP}$ at peak lay, \%HDP at peak lay, egg number, egg mass and mortality except for age at $50 \%$ lay. Phytase diet had the highest numerical value for weight of first egg $(54.28 \mathrm{~g} / \mathrm{bird})$, although there was no 
Onimisi, Agunbiade and Omage

Table 2: Growth Performance of Pullets fed Sorghum based Diets supplemented with enzymes (12-32 weeks)

\begin{tabular}{|c|c|c|c|c|c|c|c|}
\hline \multirow{3}{*}{ Parameters (\%) } & \multirow{2}{*}{\multicolumn{5}{|c|}{ Dietary Treatments }} & \multirow{2}{*}{\multicolumn{2}{|c|}{ T6 }} \\
\hline & & & & & & & \\
\hline & $\begin{array}{l}\text { T1 } \\
\text { (Maize } \\
\text { Control) } \\
\end{array}$ & $\begin{array}{l}\text { T2 } \\
\text { (Sorghum } \\
\text { Control) }\end{array}$ & $\begin{array}{l}\text { T3 } \\
\text { (Sorghum } \\
\text { +Phytase) }\end{array}$ & $\begin{array}{l}\text { T4 } \\
\text { (Sorghum } \\
\text { +Protease) }\end{array}$ & $\begin{array}{l}\text { T5 } \\
\text { (Sorghum } \\
+ \text { G2G) }\end{array}$ & $\begin{array}{l}\text { (Sorghum+ } \\
\text { Protease } \\
+ \text { G2G) }\end{array}$ & SEM \\
\hline Initial Wt (g/bird) & 736.67 & 736.67 & 733.33 & 736.67 & 740.00 & 733.33 & 3.97 \\
\hline Final Wt (g/bird) & $1416.67^{\mathrm{a}}$ & $1356.67^{b}$ & $1343.33^{\mathrm{b}}$ & $1400.00^{\mathrm{a}}$ & $1373.33^{b}$ & $1370.00^{\mathrm{b}}$ & 18.13 \\
\hline $\begin{array}{l}\text { Weight gain } \\
\text { (g/bird) }\end{array}$ & $680.00^{\mathrm{a}}$ & $620.00^{\mathrm{b}}$ & $610.00^{\mathrm{b}}$ & $663.33^{\mathrm{a}}$ & $633.33^{b}$ & $636.67^{b}$ & 18.63 \\
\hline $\begin{array}{l}\text { Daily Weight gain } \\
\text { (g/bird) }\end{array}$ & $5.11^{\mathrm{a}}$ & $4.66^{\mathrm{b}}$ & $4.59^{\mathrm{b}}$ & $4.99^{\mathrm{a}}$ & $4.76^{\mathrm{b}}$ & $4.79^{\mathrm{b}}$ & 0.14 \\
\hline $\begin{array}{l}\text { Total Feed Intake } \\
\text { (g/bird) }\end{array}$ & $4106.7^{\mathrm{a}}$ & $3950.00^{\mathrm{b}}$ & $4043.30^{\mathrm{a}}$ & $4166.70^{\mathrm{a}}$ & $4170.00^{\mathrm{a}}$ & $3913.30^{\mathrm{b}}$ & 71.07 \\
\hline $\begin{array}{l}\text { Daily Feed Intake } \\
\text { (g/bird/day) }\end{array}$ & $30.88^{\mathrm{a}}$ & $29.70^{\mathrm{b}}$ & $30.40^{\mathrm{a}}$ & $31.33^{\mathrm{a}}$ & $31.35^{\mathrm{a}}$ & $29.24^{\mathrm{b}}$ & 0.53 \\
\hline \multicolumn{8}{|c|}{$\begin{array}{l}{ }^{\mathrm{ab}} \text { Means in the same row with dif } \\
\text { SEM= standard error of means }\end{array}$} \\
\hline \multicolumn{8}{|c|}{ Dietary Treatments } \\
\hline Parameters (\%) & $\begin{array}{l}\text { T1 } \\
\text { (Maize } \\
\text { Control) }\end{array}$ & $\begin{array}{l}\text { T2 } \\
\text { (Sorghum } \\
\text { Control) }\end{array}$ & $\begin{array}{l}\text { T3 } \\
\text { (Sorghum } \\
\text { +Phytase) }\end{array}$ & $\begin{array}{l}\text { T4 } \\
\text { (Sorghum } \\
\text { +Protease) }\end{array}$ & $\begin{array}{l}\text { T5 } \\
\text { (Sorghum } \\
+ \text { G2G) }\end{array}$ & $\begin{array}{l}\text { T6 (Sorghum } \\
\text { +Protease } \\
\text { +G2G) }\end{array}$ & SEM \\
\hline $\begin{array}{l}\text { Weight at first } \\
\text { egg(g/bird })\end{array}$ & $1416.00^{\mathrm{a}}$ & $1354.67^{\mathrm{b}}$ & $1341.33^{\mathrm{b}}$ & $1400.00^{\mathrm{a}}$ & $1376.00^{\mathrm{a}}$ & $1368.00^{\mathrm{ab}}$ & 26.54 \\
\hline $\begin{array}{l}\text { Weight of first } \\
\operatorname{egg}(g)\end{array}$ & $50.10^{\mathrm{ab}}$ & $51.50^{\mathrm{ab}}$ & $54.28^{\mathrm{a}}$ & $50.82^{\mathrm{a}}$ & $52.87^{\mathrm{a}}$ & $48.98^{\mathrm{ab}}$ & 2.65 \\
\hline $\begin{array}{l}\text { Age at first egg } \\
\text { (days) }\end{array}$ & $148.67^{\mathrm{a}}$ & $165.33^{\mathrm{d}}$ & $160.67^{\mathrm{d}}$ & $156.67^{\mathrm{b}}$ & $154.67^{\mathrm{b}}$ & $153.00^{\mathrm{c}}$ & 3.00 \\
\hline $\begin{array}{l}\text { Age at } 10 \% \text { lay } \\
\text { (days) }\end{array}$ & $158.33^{\mathrm{a}}$ & $176.67^{\mathrm{c}}$ & $165.33^{\mathrm{b}}$ & $160.67^{\mathrm{b}}$ & $159.67^{\mathrm{a}}$ & $163.67^{\mathrm{b}}$ & 3.17 \\
\hline $\begin{array}{l}\text { Age at } 50 \% \text { lay } \\
\text { (days) }\end{array}$ & 180.33 & 194.00 & 186.00 & 194.33 & 186.00 & 188.33 & 7.59 \\
\hline $\begin{array}{l}\text { Age at Peak lay } \\
\text { (days) }\end{array}$ & $217.33^{\mathrm{b}}$ & $211.33^{\mathrm{ab}}$ & $217.33^{b}$ & $217.33^{\mathrm{b}}$ & $218.00^{\mathrm{b}}$ & $208.00^{\mathrm{a}}$ & 4.87 \\
\hline $\begin{array}{l}\text { Number of Eggs at } \\
\text { Peak lay }\end{array}$ & $23.00^{\mathrm{ab}}$ & $22.00^{\mathrm{b}}$ & $24.00^{\mathrm{a}}$ & $24.00^{\mathrm{a}}$ & $21.00^{\mathrm{b}}$ & $21.00^{\mathrm{b}}$ & 1.00 \\
\hline $\begin{array}{l}\% H H P \text { at Peak } \\
\text { Lay }\end{array}$ & $75.60^{\mathrm{ab}}$ & $70.20^{\mathrm{b}}$ & $78.84^{\mathrm{a}}$ & $77.76^{\mathrm{a}}$ & $69.12^{\mathrm{b}}$ & $66.96^{\mathrm{b}}$ & 3.81 \\
\hline $\begin{array}{l}\text { \%HDP at Peak } \\
\text { Lay }\end{array}$ & $77.67^{\mathrm{ab}}$ & $71.24^{\mathrm{b}}$ & $81.09^{\mathrm{a}}$ & $78.84^{\mathrm{a}}$ & $70.20^{\mathrm{b}}$ & $66.96^{\mathrm{b}}$ & 4.12 \\
\hline Egg number/bird & $36.00^{\mathrm{a}}$ & $24.00^{\mathrm{c}}$ & $31.00^{\mathrm{b}}$ & $31.00^{\mathrm{b}}$ & $34.00^{\mathrm{ab}}$ & $30.00^{\mathrm{b}}$ & 2.00 \\
\hline Egg Mass(g/bird) & $867.70^{\mathrm{a}}$ & $510.70^{\mathrm{d}}$ & $776.00^{\mathrm{b}}$ & $765.00^{\mathrm{b}}$ & $844.30^{\mathrm{a}}$ & $700.00^{\mathrm{c}}$ & 108.50 \\
\hline Mortality (\%) & $4.00^{\mathrm{b}}$ & $1.00^{\mathrm{ab}}$ & $4.00^{\mathrm{b}}$ & $1.00^{\mathrm{ab}}$ & $1.00^{\mathrm{ab}}$ & $0.00^{\mathrm{a}}$ & 1.00 \\
\hline
\end{tabular}

significant difference $(p>0.05)$ among the whole treatments in terms of weight of first egg. There was no significant difference ( $>0.05$ ) among maize control, phytase, and protease diets with respect to the number of eggs at peak lay, \%HHP at peak lay, and $\% \mathrm{HDP}$ at peak lay respectively. Maize control diet was significantly $(\mathrm{p}<0.05)$ better for age at first egg (148.67 days) and numerically better for egg number (36.00) 


\section{Sorghum based diets supplemented with enzymes}

compared to the other treatments.

The G2G diet was comparable to the maize control diet for weight at first egg, weight of first egg, age at 10\% lay, egg number, and egg mass. Dietary treatment differed significantly for weight at first egg, age at first egg, age at 10\% lay, number of eggs at peak lay, $\%$ HHP at peak lay, $\%$ HDP at peak lay, egg number, egg mass, and mortality. However, there were no significant differences among the treatments for weight of first egg, and age at 50\% lay. These results are similar to values obtained by Lumpkins et al. (2005) and Roberson et al. (2005). Both authors conducted experiments with laying hens incorporating up to $15 \%$ DDGS with no negative effects on egg production. Typically, enzymes added to layer feed appear to have little effect on egg mass but improve feed efficiency (Vukic Vranjes and Wenk, 1993; Benabdeljelil and Arbaoui, 1994), and energy utilization (Wyatt and Goodman, 1993). Wyatt and Goodman (1993) reported that corn-fed layers exhibited better feed efficiency than those fed enzyme supplemented barley-based diets. Nevertheless, enzyme supplementation improved the utilization of sorghum diets in the present study such that the egg mass was not similar among dietary treatments. Mathlouthi et al. (2003) reported no effect of a multi-enzyme complex on early laying egg performance, and their results were contrary to the observations in the current trial. These differences could be due to environmental differences such as enzyme types, climatic conditions and experimental set up of the birds. Furthermore, Gunawardana et al. (2009), using Hy-Line W-36 hens, found no significant effect of a multi-enzyme blend (Robavio ${ }^{\mathrm{TM}}$ ) on hen feed intake and performance. Harms et al. (2000) also reported no significant effect of multi-enzyme supplementation in producing hens.

Egg weight was affected by enzyme supplementation in this study. Wu et al. (2005) reported that diets supplemented with $\beta$-mannanase, a part of the multienzyme Rovabio, significantly increased egg weight in some weeks only. However, no definite pattern was observed for most of the egg production traits. Egg production did not have a definite pattern when layers were fed diets with sorghum supplemented with enzyme or when sorghum was the sole cereal in the diet (Parthasarathy et al., 2005). However, phytase supplementation in pullet diet effectively increased the weight of first egg and \% HDP at peak lay, hence, phytase has practical advantages and it may be strongly recommended for use in sorghum based diets. Age at first egg, age at $10 \%$ lay, age at peak lay and number of eggs at peak lay was not influenced by enzyme supplementation as compared with the maize based diet without enzyme supplementation that had earliest lay. Age at $10 \%$ egg production was 150 to 178 days for commercial layers in data reported by Ryan et al. (1998) and result from this study was within the value of 148.67-165.33 days.

The results from this study indicated that enzyme supplementation significantly affected egg mass compared to the control group. These results are contrary with the report of Jalal et al. (2007), who reported that Avizyme $\AA$ supplementation did not have a significant effect on egg mass. On the other hand, most recent research with laying hens has shown improved egg mass among varying laying hen strains when Avizyme ${ }^{\circledR}$ of different enzyme form was used (Douglas et al., 1990; Sohail and Roland, 1999, and Scheideler et al., 2005).

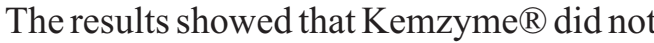
significantly affect egg mass compared to the control group in Matrouh hens. 


\section{Onimisi, Agunbiade and Omage}

However, when Avizyme ${ }^{\circledR}$ and Kemzyme ${ }^{\circledR}$ were added together, the egg mass was enhanced than the control group or Kemzyme ${ }^{\circledR}$ group. Hen day production was best for dietary treatment supplemented with protease and phytase. Roberts and Choct (2006) however, reported that phytase supplementation caused a significant increase in hen-day egg production but egg weight at the same time decreased significantly.

Higher numerical egg weight was obtained in hens of phytase, protease, and G2G diets compared to the control groups (maize and sorghum diets), likely because of an improvement in the digestion and utilization of protein by the hens resulting from phytase and protease supplementation in the diet. Hen house production differed and showed the superiority of phytase and protease based diets over the other diets as also evidenced in the mortality ratio where the control and singular enzyme supplementation diets had the highest mortality accounting for reduction in HHP. The ranges of $69.12 \%-78.84 \%$ agreed with the report of $69.00 \%-81.67 \%$ as reported by Tuleun et al. (1998) in laying hens.

Although the age at first egg, age at 10\% lay, and age at peak lay were not significantly better in Phytase and Protease diets, and also the number of eggs at peak lay, \%HHP, and $\%$ HDP were all significantly better, which translates to the effectiveness of phytase and protease as phytate degrading enzyme and protein degrading enzyme respectively.

\section{Conclusion}

Supplementation with protease enzyme improved the utilization of sorghum for growth performance while both phytase and protease improved utilization for egg performance traits. Sorghum supplemented with phytase and protease can therefore be incorporated in growers and layers diets of egg type chickens, without negative effect on growth and early laying performance.

\section{References}

Abubakar, M., Doma, U. D., Kalla, D. J. U., Ngele, M. B. and Augustine, C. L. D. 2006. Effects of dietary replacement of maize with malted and unmalted sorghum on performance of weaner rabbits. Livestock Research for Rural Development. Volume 18, Article \#65.

Ajaja, K., Agbede, J. O. and Aletor, V. A. 2002. Replacement value of sorghum dust for maize in diets for broiler chicks. Proc $27^{\text {th }}$ Ann. Conf. Nig. Soc. for Anim. Prod. March 17 - 21, Federal University of Technology, Akure, pp. 109-112.

Benabdeljelil, K. and Arbaoui, M. I. 1994. Effects of enzyme supplementation of barley based diets on hen performance and egg quality. Animal Feed Science and Technology, 48, 325-334.

Douglas, J. H., Sullivan, T. W., Bond, P. L. and Struwe, F. J. 1990. Nutrient composition and metabolizable energy values of selected grain sorghum varieties and yellow maize. Poultry Science. 69: 1147-1155.

Etuk, E. B. 2008. Nutrient composition and feeding value of sorghum for turkeys. Ph.D Thesis, Federal University of Technology, Owerri, Nigeria.

Etuk, E. B. and Ukaejiofo, U. R. 2007. Tannin content and dietary effects of brown coat coloured sorghum on the performance of young local turkey. Animal Production Resource Advance, 3(2): 86-90.

Graham, K. K., Kerely, M. S., Firman, J. 
D. and Allee, G. L. 2002. The effect of enzyme treatment of soybean meal on oligosaccharide disappearance and chick growth performance. Poultry Science, 81:1014 - 1019.

Gunawardana, P., Roland, D. A. and Bryant, M. M. 2009. Effect of dietary energy, protein, and a versatile enzyme on hen performance, egg solids, egg composition, and egg quality of Hy-Line W36 hens during second cycle, phase two. Journal of Applied Poultry Resource. 18:4353.

Harms, R. H., Olivero, V. and Russell, G. B. 2000. A comparison of performance and energy intake of commercial layers based on body weight or egg weight. Journal of Applied Poultry Research. 9:179184

IAR. 1999. Code and description of crop varieties released by Institute of Agricultural Research, Ahmadu Bello University, Samaru, Federal Ministry of Science and Technology, Abuja,pp. 14-15.

Jalal, M. A., Scheideler, S.E. and Pierson, E. 2007. Strain responses of laying hens to varying dietary energy with and without enzyme supplementation. Journal of Applied Poultry Resource, 16:289295.

Khusheeba., M. and Sajid, M. 2013. A review on role of exogenous enzyme supplementation in poultry Production. Emirates Journal of Food and Agriculture, 25 (1): 6680.

Lumpkins, B. S., Batal, A. B. and Dale, N. M. 2005. Evaluation of distillers dried grains with solubles as a feed ingredient for broilers. Poultry Science. 83:1891-1896.

Marsman, G. J., Gruppen, H., Van der poel, A. F., Kawakkel, R. P., Verstegen, M. W. and Voragen, A. G. 1997.. The effect of thermal processing and enzyme treatments of soybean meal on growth performance, ileal nutrient digestibilities, and chime characteristics in broiler chicks. Poultry Science, 76:864-872.

Mathlouthi, N., Lallès, J. P., Lepercq, P., Juste, C. and Larbier, M. 2003. Xylanase and $\beta$-glucanase supplementation improve conjugated bile acid fraction in intestinal contents and increase villus size of small intestine wall in broiler chickens fed a rye-based diet. Journal of Animal Science, 80: 2773-2779

Maunder, A. B. 2002. Sorghum worldwide. In Sorghum and Millet Diseases. Iowa State Pres, Blackwell Publ. Comp. Ames, Iowa.

Munir, K. and Maqsood, S. 2013. A review on role of exogenous enzyme supplementation in poultry production. Emirate Journal of Food and Agriculture. 25 ( 1 ): $66-80$ d o i : 10.9755/ejfa.v25i1.9138

Olabanji, R. O., Ojebiyi, O. O., Tona, G. O. and Olaogun, O. 2009. Haematological and Serum Biochemical Response of growing Rabbits fed Diets Containing Mango ( Mangifera indica) Seed Kernel Meal. Proc. of $14^{\text {th }}$ Ann. Conf. of ASAN. Sept. 14th-17th. LAUTECH Ogbomosho. pp. 270273.

Ovimaps, 2015. Ovi location map: Ovi 


\section{Onimisi, Agunbiade and Omage}

earth imagery date; July $5^{\text {th }}$.

Pariza, M. W. and Cook, M. 2010. Determining the safety of enzymes used in animal feed. Registered. Toxicology and Pharmacology. 56:332-342.

Parthasarathy, P. R., Gurava, K. R., Reddy, V. S. and Gowda, C. L. 2005. Linking producers and processors of sorghum for poultry feed: A case study from India. International lnstitute of Crop Research in Semi-Arid Trop. (ICRISAT).

Pettersson, D. and Aman, P. 2007. Production responses and serum lipid concentration of broiler chicken fed diets based on oat bran and extracted oat bran with and without enzyme supplementation. Journal of Science, Food and Agriculture, 58: 569-576

Roberson, K. D., Kalbfleisch, J. L., Pan, W., and Charbeneau, R. A. 2005. Effect of corn distillers dried grains with solubles at various levels on performance of laying hens and egg yolk color. International Journal Poultry Science, 4(2):44-51.

Roberts, J. R. and Choct, M. 2006. "Effects of commercial enzyme preparations on egg and eggshell quality in laying hens". British Poultry Science 47(4) : 501-510.

Ryan, D. P., Bao, B., Griffith, M. K. and Williams, G. L. 1998. Metabolic and luteal sequelae to heightened dietary fat intake in under nourished, anestrous beef cows induced to ovulate. Journal of Animal Science, 73:2086-2093.

S.A.S. 2001. Statistical analysis system. SAS/STAT User's guide version 6. Vol 2, SAS Inst-Inc. carry, N.C 846.

Silversides, F. G. and Hruby, M. 2009.
Feed formulation using phytase in laying hen diets. Journal of Applied Poultry Resources, 18:1522.

Smithison, K. W., Millar, D. B., Jacobs, L. R. and Gray, G. M. 1981. Intestinal diffusion barrier: Unstirred water layer or membrane surface mucoys coat. Science. 214: $1241-1244$.

Sohail, S. S. and Roland, D. A. 1999. Influence of supplemental phytase on performance of laying hens. Poultry Science, 78:550-555.

Subramanian, V. and Metta, V. C. 2000. Sorghum grain for poultry feed. In: Technical and Institution Options for Sorghum Grain Mold Management. Proc. International Consultation. Chandrasher, A., Bandyopadhayi, R. and Hall, A. J. (eds.). International Crop Research for the Semi-Arid Tropics (ICRISAT). Patacheru 502 - 504, Andhra Pradesh, India, pp. 242- 247 .

Tuleun, C. D., Njoku, P. C. and Yaakugh, I. D. I. 1998. The performance of $\mathrm{p} \mathrm{u} 1 \mathrm{let} \mathrm{ch}$ i c s f e d Roxazyme ${ }^{\circledR} .3{ }^{r d} A S A N$ Conference, Lagos. Pp 74-76.

Vukic, V. M. and Wenk, C. 1993. Influence of dietary enzyme complex on broiler performance in diets with and without antibiotic supplementation. In Wenk, C.; Boessinger, M., ed., Enzymes in animal nutrition. Kartause Ittingen, Thurgau, Switzerland. pp. 152-155.

Wu, G., Bryant, M. M., Voitle, R. A and Roland, D. A. 2005. Effect of $\beta$ mannanase in corn-soy diets on commercial Leghorns in second cycle hens. Poultry Science. 84: 
894-897.

Wyatt, C. L. and Goodman, T. 1993.

Utilisation of feed enzymes in

laying hen rations. Journal of Applied Poultry Research, 2 : 6874.

Received $29^{\text {th }}$ December, 2016

Accepted: $4^{\text {th }}$ March, 2017 